\title{
Court staff training on EU law: an unsolvable puzzle?
}

Key challenges and presentation of a pilot training project

\author{
Anastasia Patta 1 \\ Published online: 2 July 2019 \\ (C) Europäische Rechtsakademie (ERA) 2019

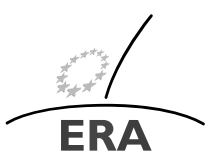 \\ EUROPÄISCHE RECHTSAKADEMIE \\ ACADEMY OF EUROPEAN LAW \\ ACADEMIE DE DROIT EUROPEEN \\ ACCADEMIA DI DIRITTO EUROPEO \\ TRIER - TREVES - TREVIRI
}

For the key players of the EU Member States' justice systems, such as judges, prosecutors and lawyers, continuous training on EU law is now more accessible than ever before. In 2011, the European Commission set a goal of ensuring that half of all 800000 legal practitioners in the EU are trained in EU law or in the national law of another Member State by 2020. ${ }^{1}$ This target has been surpassed in 2018, two years ahead of schedule. In 2017, more than 180000 legal practitioners received training on EU law or on the law of another Member State, adding yet another record number to the statistics. ${ }^{2}$ The participation ratio is high for most of the legal professions (for e.g. $54.13 \%$ of all judges, $35.05 \%$ of all prosecutors, and $27.03 \%$ of all notaries in the respondent Member States) with one striking exception: court staff, with a mere $3.23 \%$.

The annual 5\% target of trained court staff required to reach the 2011 objective was reached by only six Member States (for which data are available), namely Bulgaria, the Czech Republic, Estonia, Finland, Germany and the Netherlands. ${ }^{3}$ Although this is a slightly better result than in past years, it is far from satisfying. The question must be asked as to why providing training activities for this legal profession has yet to bear fruit.

\footnotetext{
${ }^{1}$ Communication from the Commission to the European Parliament, the Council, the European Economic and Social Committee and the Committee of the Regions of 13 September 2011_Building trust in EU-wide justice: a new dimension to European Judicial Training (COM (2011) 551 final) [1].

${ }^{2}$ Report on European judicial training 2018 published by the European Commission [2].

${ }^{3}$ See Report on European judicial training 2018, p. 12 [3].
}

$凶$ A. Patta, LL.M. apatta@era.int

1 Course Director, Private Law, Academy of European Law (ERA), Trier, Germany 
Court staff as a legal profession having specific training needs, which are different from the other branches of the judiciary, stayed under the radar for a long time. The 2014 Study on 'the state of play of court staff training in EU law and promotion of cooperation between court staff training providers at EU level'4 stated that "about half the court staff undertaking an induction period in 2012 did follow at least one training activity with EU law aspects. However these sessions are of very short duration, very fragmented and cannot be considered structured enough to build the habit of considering EU law in national procedures amongst the newly recruited court staff" and continued that "the training in EU law that is made available through continuous training is so limited that it cannot be considered to compensate the lack of EU law training during the induction period". At the same time the study showed that certain activities with EU law aspects lie at the heart of court staff's judicial work. "Mapping out the tasks of court staff around a list of topics which have some EU law aspects provided the necessary arguments for increasing the number of training activities on EU law since now it can be demonstrated that in each Member State there are court staff who need thorough training in EU law to fulfil their tasks and duties".

The DG Justice and Consumers' Conference on court staff training in 2015 came to similar conclusions and recognised the need for training activities specifically targeted at the Member States' court staff. As of 2016 court staff training has also been one the priorities of the judicial training call for proposals under the Justice Programme. ${ }^{5}$ These initiatives have raised the awareness on the need for targeted training for court staff, but have not provided answers to the main challenges that training providers are facing when planning such training activities at national and especially EU level.

As EU Commissioner for Justice Vera Jourova recently stated "identifying the needs of some practitioners, such as court staff, as regards training on EU law is still a challenge". 6 There are several reasons for this: the diversity of educational background and legal status of court staff in each country, the wide diversity of responsibilities and specific roles of this profession and the lack of cross-border communication and cooperation of national court staff training providers.

Court clerk, court secretary, court assistant, judicial counsellor, court advisor, assistant judge, judicial operator, legal assistant are just some of the titles used by Member States to describe the professional category of 'court staff'. The variety of titles reflects inter alia the diversity of educational background and legal status of court staff in each country. Not all court staff have received higher education in law prior to accessing this profession, as having a secondary high-school diploma is sufficient condition for access in some Member States. Equally diverse is the recruitment procedure that can take the form of a state/regional exam, an oral interview by the head of court or simply a test on practical skills. It should come as no surprise that the general responsibilities of court staff thus range from purely technical and administrative tasks to legal research and assistance in drafting court decisions. There are different

\footnotetext{
${ }^{4}$ Grant Agreement No JUST/2012/JUTR/PR/0064/A4 —European Judicial Training: Lot 3-Study on the state of play of court staff training in EU law and promotion of cooperation between court staff training providers at EU level.
}

${ }^{5}$ See Annex to 2016 Annual Work Programme Justice Programme, p. 17 [4].

${ }^{6}$ See Report on European judicial training 2018, p. 1. 
types of court staff not only across Member States but also within each country. A country can employ technical staff in its courts as well legal assistants for judges and both would fall under the general category of 'court staff'. A uniform definition that encompasses all types of court staff and would be applicable to all EU Member States seems unlikely and is perhaps not that relevant-at least not when it concerns the provision of training on EU law.

Not all responsibilities and tasks of all types of court staff translate into training needs on EU law. The report on "European Judicial Training 2018" stressed that "court staff in charge of procedural tasks (e.g. filling forms) do not need cross-border training to improve their performance. Their specific training needs depend on the individual tasks of each of the professionals. The situations are different in all the EU Member States. They need to be mapped." And this might be the biggest challenge of all. Mapping the specific roles and subsequently training needs of court staff on EU law is a vital prerequisite for the provision of training that is both relevant and useful for the court staff's work. A first attempt was made in the framework of the abovementioned 2014 Study that provided an important overview of general responsibilities involving EU law aspects, but which was far from being detailed and coherent enough for each Member State. A recently published call for tenders ${ }^{7}$ by the European Commission for a 'study on the training needs of court staff on EU law in the EU' aims at 'taking the 2014 pilot project study a step further, building on the learnings and recommendations stemming from the different past and ongoing studies, conferences and projects" and thus providing a clearer, more comprehensive picture on the different court staff's tasks that involve aspects of EU law as well as the training needs that derive from carrying out those tasks. The study also envisages to tackle the common issue of having different types of court staff in each country by listing those court staff professions who perform tasks, which require EU law training, thus facilitating the identification of the right target group from each Member State. In order to achieve this, there will be a need to "map in details all the different court staff professions in the EU Member States and to define all their tasks in such a way that allows comparisons across Member States". 8

A key factor for the success of this exercise will be the cooperation of national court staff training providers. For a long time there has been a lack of cross-border communication and cooperation of those training providers, a situation that added to the challenges faced when planning training activities at regional or European level. Contrary to the existence of national structures dedicated exclusively to train a certain legal profession, such as the national judicial schools providing initial and continuous training for judges, no such structure exists with respect to training court staff in the majority of Member States. The variety of court staff types has resulted to a range of structures in charge of their training, from national ministries of justice and courts to judicial academies of councils and prosecutors' offices. Bringing all those providers together and engaging them to an exchange of information and experiences is essential for putting together all the pieces.

\footnotetext{
${ }^{7}$ Call for Tender No JUST/2018/JACC/PR/CRIM/0131-Study on the training needs of court staff on EU law in the EU [5].

${ }^{8}$ See Call for Tender No JUST/2018/JACC/PR/CRIM/0131—Study on the training needs of court staff on EU law in the EU, p. 9.
} 
The last essential piece in this complicated puzzle is no other than the court staff themselves. The provision of court staff training on EU law will only bear fruit if awareness is raised of the increasing need to receive continuing training on EU law. Not only is it important that the right target group is reached-which as seen above is not an easy task - but they will also have to be presented with an attractive and convincing training concept and methodology. Training activities will have to be adapted to the concrete needs of court staff, increase awareness of the EU law aspects in their tasks and motivate them to further enrol in EU law training activities.

In 2018 the Academy of European Law (ERA) and the European Judicial Training Network (EJTN) were awarded an EU grant for a joint training project aiming at tackling the abovementioned gaps and deficiencies in training court staff on EU law. ${ }^{9}$ This project is being supported by 23 national bodies responsible for court staff training in nineteen EU Member States (Austria, Belgium, Bulgaria, Croatia, the Czech Republic, Estonia, Finland, France, Germany, Hungary, Italy, Latvia, Lithuania, the Netherlands, Poland, Portugal, Romania, Slovenia and Spain). The project will have a total duration of three years and require several steps to ensure that court staff in Europe can benefit from its results in an innovative and valuable manner.

The project aims to organise practical training events for court staff in the specific area of cross-border civil litigation by creating a standardised training package that will be reusable in future training activities. In order to guarantee the usefulness of the training to be offered and of the materials to be produced, it was essential to already take into consideration during the conception phase of the project the existing challenges that were analysed above. Which types of court staff will the project target? Which concrete area of EU law will be the training focus? How to ensure the interest and engagement of court staff from all over Europe?

The national court staff providers should be in the position to easily identify which types of their court staff could and should benefit from the project's activities. The following functional definition was thus adopted and circulated to all institutions involved from the very beginning: personnel of a court—regardless of their formal title or education-who have certain judicial or procedural functions and need to apply EU law procedures to fulfil those functions. Relevant judicial or procedural functions include inter alia: enforcement of court decisions, assistance to judges, service of judicial and extra-judicial documents, cross-border cooperation in civil matters (for e.g. completing requests to courts in other countries).

Although there is a wide variety of training needs on EU law, it was crucial to identify those concrete tasks and training needs resulting from EU law instruments and cross-border cooperation common to all jurisdictions. As laid down in the 2014 Study, cross-border civil law procedures lie at the heart of court staff's judicial work. It was therefore decided to cover the following EU instruments: (i) Brussels I Regulation (recast), (ii) European Enforcement Order, (iii) European Payment Order, (iv) European Small Claims Procedure, (v) Service of documents Regulation and (vi) Taking of evidence Regulation.

In order to familiarise court staff with the relevant EU acquis and to increase their confidence in their future using of the available legal instruments and procedures,

\footnotetext{
${ }^{9}$ Grant Agreement No 806998 - Better applying European cross-border procedures: legal and language training for court staff in Europe-Court Staff Training [6].
} 
ERA and EJTN focused on providing interactive and well-structure training, as well as improving the court staff's English communication skills. Training based on solving coherent practical case studies, requiring the active involvement of participants and thus steering a continuous exchange of knowledge, has been identified as a recommendable training methodology. When dealing with cross-border cases court staff should be able to communicate with and understand each other. Mutual understanding is a sine qua non for European integration. Former studies have "recommended to enhance the necessary linguistic skills of court staff" and to "develop more activities in legal English terminology for court staff". Interactive and practical training events combining both English language training on legal terminology and training on EU legal instruments have been considered to be the best approach.

The first milestone of the project was the development of the training package which will form the basis for the planned seminar series. The training materials for the provision of legal training mainly consist of case studies on the EU civil law instruments covered by the project.

Each case study includes the case scenario, suggested solutions as well as the necessary background materials and methodological advice for its implementation. The materials were drafted in English by three renowned EU law experts. For the provision of language training a manual on legal terminology in English including language exercises was developed by a linguistic expert. The exercises focus on developing four skills: reading, writing, speaking and listening. From the beginning of the preparation phase a short questionnaire was sent to all involved national bodies with concrete questions on the tasks and training needs of court staff in the relevant areas. The answers were forwarded to the experts with the aim of adapting the materials to best suit the project's purposes.

Once developed, the materials were presented and discussed with national experts and training providers, appointed by the project's partnership, in the framework of a 2-day coordinating meeting that took place at ERA's premises in April 2019. During this meeting the national experts became familiarised with the training package, discussed its practical relevance and contributed to improving it. The same people will then be responsible for testing the materials in real conditions during the planned seminar series. As experts from 18 different EU Member States came together, the coordinating meeting also offered a unique opportunity and platform to reconfirm the court staff's training needs and to exchange information on the various existing training systems.

The project partnership is currently working on the organisation of the seminar series. A series of 20 legal seminars and 13 language training events around Europe, aimed at approximately 930 court staff, will be implemented over the next 2.5 years.

The legal seminars will have a duration of 1.5 days and will be addressed to max. 30 participants each. The training will be based on introductory face-to-face presentations and the solving of the developed case studies. In order to offer in-depth training on the applicability of the European cross-border legislative instruments, two different seminar programmes will be drafted, each focusing on one of the following topics:

(i) Cross-border civil litigation: facilitating the handling of cross-border cases, and (ii) Cross-border enforcement of civil law claims: simplified European procedures. 19 national legal seminars will be organised by the supporting organisations with the 
support of the coordinator. National trainers will run each seminar, the seminar leader being the national expert who participated in the coordinating meeting of the project. Each seminar will be held in the respective national language. The respective supporting organisations will provide the translation of the necessary case studies for the implementation of their national seminar. One pan-European legal seminar will be organised by ERA and EJTN in Brussels and will be open to court staff coming from all EU Member States.

In parallel to the organisation of the purely legal seminars, a series of 13 language English training events will be implemented by ERA with the support of the partnership. Each event will have a duration of three days in total (two full days and two half days) and will be addressed to maximum 26 court staff from various EU Member States. As the proposed events comprise English language training on the one hand, and training on the EU civil cross-border procedures on the other, participants will be divided into two groups upon assessment of their linguistic strengths and weaknesses. This will guarantee a workable number for in-depth language training and will not influence the transnational character of the event, as participants will originate from at least seven EU Member States. This approach will also allow parallel sessions during which one group will receive legal and the other one language training, thus ensuring that all essential aspects can be covered during three days. This does not exclude the implementation of joint sessions where deemed appropriate. The involved trainers will have at their disposal the training materials (case studies \& linguistic manual) specially developed for the implementation of these training events.

All information related to the project's activities will be centralised in the specially developed project web page. ${ }^{10}$ The entire training package developed, (partly) available in 16 official languages of the EU will also be freely available and downloadable even after the project's finalisation. And exactly here lies perhaps the biggest potential of this pilot project. The development of standardised training materials in so many different languages increases the potential for further use in the context of future national, regional or pan-European training. The widespread partnership of the project forms the main channel of dissemination and will ensure that information about the developed training package reaches virtually all corners of Europe.

The project's results are expected to be beneficial not only for the final recipients, namely the court staff, but also for their training providers. This project is building a culture of cross-border cooperation by bringing together court staff training providers from 18 EU Member States. It will create a foundation for efficient, continuous and cost-effective networking and cooperation between national training providers, which could ultimately lead to an increasing number of cross-border training activities for court staff.

Recently, ERA and EJTN were awarded an EU grant for the implementation of a similar court staff training project focusing this time on European criminal law. ${ }^{11}$ The concept, approach and methodology chosen for these projects seem to suit the needs and expectations of national court staff training bodies as they joined both projects in

\footnotetext{
${ }^{10}$ Detailed information can be found on the project's web page: https://court-staff.legaltraining.eu/ [7].

${ }^{11}$ Proposal No 851999-Better applying European criminal law: legal and language training evens for court staff across Europe [8].
} 
great numbers. Although these projects cannot be expected to provide final answers to the challenges faced when offering training on EU law for court staff, they do nevertheless tackle some of the existing gaps: by creating an established network of European and national training providers and experts, they contribute to the expansion and intensification of cross-border cooperation and to a better understanding of the various court staff training needs; by providing targeted and innovative training in an EU environment for hundreds of court staff, they raise awareness of the increasing need for this profession to receive continuing training on EU law. In this way they add yet another important piece to the puzzle of court staff training that might not be unsolvable after all.

Publisher's Note Springer Nature remains neutral with regard to jurisdictional claims in published maps and institutional affiliations.

\section{References}

1. Communication from the Commission to the European Parliament, the Council, the European Economic and Social Committee and the Committee of the Regions of 13 September 2011-Building trust in EU-wide justice: a new dimension to European Judicial Training (COM (2011) 551 final)

2. Report on European judicial training 2018 published by the European Commission

3. Grant Agreement No JUST/2012/JUTR/PR/0064/A4-European Judicial Training: Lot 3-Study on the state of play of court staff training in EU law and promotion of cooperation between court staff training providers at EU level

4. Annex to 2016 Annual Work Programme Justice Programme

5. Call for Tender No JUST/2018/JACC/PR/CRIM/0131—Study on the training needs of court staff on EU law in the EU

6. Grant Agreement No 806998-Better applying European cross-border procedures: legal and language training for court staff in Europe-Court Staff Training

7. https://court-staff.legaltraining.eu/

8. Proposal No 851999-Better applying European criminal law: legal and language training evens for court staff across Europe 